\title{
Internal Control and Accountability of Credit Cooperatives
}

\author{
Jessa Q. Beloy, CPA, CTT, MSA \\ The University of Mindanao
}

\begin{abstract}
This study aims to guide not only credit cooperatives but all financial institutions in improving accountability by establishing and implementing an effective and well-organized system of internal control. This study determined which domain of internal control best influenced the accountability of credit cooperatives in Panabo City. It applied the quantitative, nonexperimental research design utilizing correlational technique, with 108 employees of credit cooperatives as the respondents selected through total population sampling. The researcher adapted and modified questionnaires to measure internal control and accountability. The Mean, Pearson r, and Regression Analysis were used as statistical treatments. Results revealed that the level of internal control of credit cooperatives was very high across all indicators. Similarly, the study revealed a very high level of accountability among credit cooperatives as perceived by the employees. Based on the findings of the study, it showed that internal control is significantly correlated to the accountability of credit cooperatives, with a p-value less than the level of significance. The overall result disclosed that internal control has significant influence on the accountability of credit cooperatives. Control activities was the domain of internal control that best predicts accountability of credit cooperatives.
\end{abstract}

Keywords - internal control, accountability, credit cooperative

\section{INTRODUCTION}

$I^{2}$ ncidences of fraud and misconduct through the years have raised the awareness and demand for accountability from all types of organizations (Morehead, 2007). In 2008, the failure of the Lehman Brothers was the largest case of bankruptcy in United States history which shifted toward the accountability of management for not disclosing various transactions (Azadinamin, 2013). Nowadays, in cooperatives, problems and challenges on accountability arise when the management, acting as agents, may be involved in activities that have conflicting interest with the principal or its members (Mohamad, Othman, \& Mohamed, 2013). In Bangladesh, existence of numerous problems such as administrative failure, poor decisions and high occurrence of corruption can be traced to the absence of an effective system of accountability (Huque, 2011). Also, in Zimbabwe, it was found out that lack of accountability resulted from unethical behaviors of the management causing serious negative implications (Zvavahera \& Ndoda, 2014).

Moreover, Mohamad et al. (2013) mentioned that accountability is an essential component to ensure that the conduct of the cooperative is carried out with effectiveness and high integrity. Accountability, therefore, is crucial to guard the organization against the risk of unauthorized exercise of power granted by principals to agents (Keay \& Loughrey, 2015). Thus, establishment of accountability in cooperatives will give the members the right to make the management responsible for their assets, if these are protected, and for the value produced if it is consistent with their interest (Stier, 2004). Further, if accountability is held in an organization, it will hold individuals responsible for the consequences of their decisions and actions.

In connection with this, to maintain a certain level of accountability, cooperatives should have a well-organized and good framework. Significantly, Morehead (2007) posits that one way to demonstrate accountability is by a strong internal control. As expressed by Noorvee (2006) and Kumuthinidevi (2016), internal control will make sure that operations are effective and efficient, risk of asset loss are reduced, and accuracy and reliability of financial reporting and compliance with laws and regulations are ensured. Therefore, an effective internal control helps in promoting accountability by making it certain that consequences of an action and decisions will be accounted for.

Therefore, in this milieu, the researcher takes interest to conduct the study of internal control and accountability of credit cooperatives. There are existing studies on the two variables as mentioned above; however, those studies dealt only with identifying factors in a foreign context and only on the main variables. Also, studies on the relationship between internal control and accountability have not been initiated in the context of credit cooperatives. Whereas, in this study, the researcher covers the specific domain of each variable and the concentration is on the local set-up. Thus, the urgency of conducting this study is to find out if internal control may affect accountability of credit cooperatives.

\section{Research Objective}

This study identified which domain of internal control best influences accountability of credit cooperatives in Panabo City. Specifically, it sought to attain the following objectives:

1. To ascertain the level of internal control of credit cooperatives in Panabo City in terms of:
1.1. control environment;
1.2. control activities;
1.3. risk assessment;
1.4. information and communication; and
1.5. monitoring. 
2. To assess the level of accountability of credit cooperatives in Panabo City in terms of:

\section{1. participation; \\ 2.2. evaluation; \\ 2.3. fiscal compliance.}

3. To determine the significance of the relationship between internal control and accountability of credit cooperatives in Panabo City

4. To identify which domain of internal control best influences the accountability of credit cooperatives in Panabo City

\section{REVIEW OF RELATED LITERATURE}

To provide a framework to the investigation, selected literature related to the study are presented in this section. The review includes theories, principles, concepts and views, which have a direct relation to the variables of the study. The present study will contribute to the existing gap in the literature and will give specific contribution to the advancement of knowledge, theory and practice especially in the local setting, and on which domain of internal control significantly influences accountability of credit cooperatives.

Internal Control. Internal control has a broad definition. However, the Committee of Sponsoring Organizations of the Treadway Commission [COSO] (2013) quoted internal control as a process, effected by an entity's board of directors, management and other personnel, designed to provide reasonable assurance regarding the achievement of objectives on the following categories: reliability of financial reporting; compliance with applicable laws and; effectiveness and efficiency of operations.

Control environment. It is defined as set of processes, standards, and structures that provides the foundation for the implementation and continuity of the whole system of internal control. Further, an appropriate control environment will create a positive atmosphere that will set the rhythm of an organization so that everyone becomes aware of the relevance of the internal control. Likewise, since internal control is set up by the management, if they believe that having internal control is extremely important, then all personnel will feel the same way. In short, control environment helps an organization to set the tone in implementing effective internal control (Yurniwati \& Rizaldi, 2015).

Control activities. As mentioned by Gaku (2014), these are policies and procedures that ensure the organization carries out the management directives. It is measured by presence or absence of approvals, authorizations, verifications, reconciliations, reviews of operating performance, security of assets and segregation of duties. If control activities are not well-sighted by the management, it will cause the internal control to fail.

Risk assessment. It is a process of identification, analysis and evaluation. Besides, risk identification is the first step of risk assessment, followed by risk analysis and lastly, risk evaluation. Risk identification involves finding, recognizing and recording risks which covers identification of asset values which contains maintenance, development and security of assets, threats which are external influence and can occur by accident or on purpose, while vulnerabilities is an internal influence resulting from an ineffective and neglected security. Both can give incidents of breach of security, and existing controls which provides listings and statuses of implemented and planned security controls (Chen, 2015; Eskelinen, 2016).

Information and communication. As noted by Abiola (2013), information and communication ensure that the relevant information, outside and inside of the organization, are communicated well. With that, all information must be identified, captured and communicated in a form, and responsible personnel are given enough time for them to carry out their duties and responsibilities.

Monitoring. Indicator of internal control which refers to the set of procedures and standards in assessing the quality of control which covers ongoing and periodical evaluations of the external supervision of internal controls by the management or other parties who are outside the process (Abiola, 2013). The monitoring part will tell the organization if their internal control is properly implemented or if it is still effective and whether there are corrective actions that should be taken within the organization.

Accountability. In the study of Selaratana (2009) about accountability in Thailand's public sector, it was mentioned that in other countries and in different languages, the word accountability is used interchangeably with words such as responsibility and transparency. Nonetheless, it was quoted that accountability is an obligation, or responsibility of a person or organizations or entities to explain, answer, justify, and defend their actions or what they have done to another party who will observe, evaluate, and scrutinize that performance and they can give feedback, including reward and punishment.

Participation. It is defined by Dossing, Letshego, and Weideman (2011) as the processes in the systems that obviously accord space and time to involve the public through meetings, assemblies, consultations even through delegating certain decisions or activities for the awareness of the public. An organization to be accountable should enable stakeholders to play an active role in the decision-making processes and activities which may affect them (Blagescu, de las Casas \& Lloyd, 2005).

Evaluation. Blagescu et al. (2005) defined it as the processes through which an organization, with the involvement of key stakeholders, monitors and reviews its progress and results against goals and objectives; feeds learning from this back into the organization on an ongoing basis; and reports on the results of the process. Evaluation ensures that the organization has learned from and is also accountable for its performance. In short, the relationship between accountability and evaluation centers on learning. The evaluation process and the 
results which come after it will help the organization on future decision-making by providing information to improve its performance, thus making it more accountable to achieve its goals and objectives.

Fiscal compliance. Fiscal is a term used in relating to any government revenue, especially taxes so, fiscal compliance is complying with the government's rules and regulation e.g. paying taxes, and other financial and regulatory standards. To establish accountability across the organizations, Marenakos (2011) stated that every area of it must both comply with all the rules and regulations. With that, it is demonstrated to the key stakeholders, not just for compliance purposes only, that the organization cares for both internal and external parties. When problems arise regarding fiscal compliance of an organization, these must be acknowledged and fixed to promote accountability.

The following hypotheses were tested at the 0.05 level of significance:

1. There is no significant relationship between internal control and accountability of credit cooperatives in Panabo City.

2. There is no domain of internal control that best influences the accountability of credit cooperatives in Panabo City.

\section{Theoretical Framework}

This study is anchored on the proposition of Ntongo (2012) that there is a significant positive relationship between internal control and accountability. If internal controls are not well implemented, proper accountability cannot be realized.

This proposition agrees with the study of Steinhoff (2005), which states that the key to accountability is an effective internal control. If in case, serious problems occurred because internal control had breakdowns and the management was not able to establish a proper internal control environment or did nothing to fix the known problem, all concerned individuals need to be accountable and shall face the consequences resulting from their Inaction. Thus, it would be an excellent means of establishing accountability if the management is involved in internal control assessment and monitoring.

In addition, the proposition of Morehead (2007) also provides the theoretical framework for this study. It is pointed out that one of the primary accountability tools an organization can establish is a well-defined and functioning internal control system which can be used to provide accountability to the public, as well as to prevent and detect fraud and corruption. Absence of an effective internal control in organization will make it possible for individuals to engage in fraud and corruption, thus, manifesting low level of accountability.

Banking on the aforementioned theories, this study claims the same thesis that internal control impacts accountability.

\section{Conceptual Framework}

Presented in Figure 1 is the conceptual framework showing the variables of the study. This study investigates internal control, the independent variable, which, according to Ayyash (2017), consists of the following indicators: control environment which refers to actions, policies and procedures set by top management to clear organization values and integrity so that unethical activity will not be permitted; control activities which refers to the actions taken to address risks for the achievement of financial reporting objectives; risk assessment which refers to the identification of risk and assessment of the likelihood of risk occurring and taking certain actions to reduce risk to acceptable level; information and communication which refers to the sharing and responsibilities at all levels of the organization; and monitoring which is defined as ongoing activities or periodic assessment of the effectiveness of internal control made by management to determine that controls are operating as intended and they are modified as appropriate for changes in any conditions.

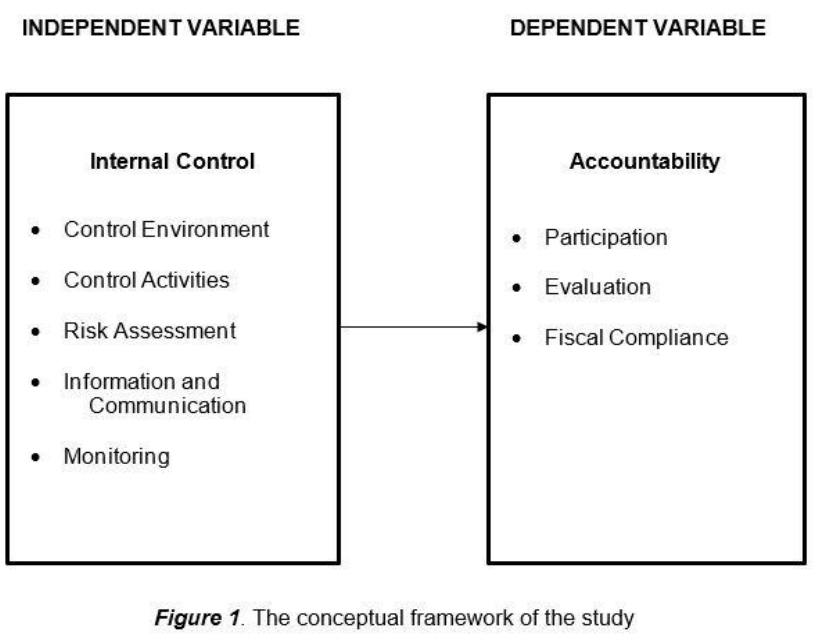

Accountability, on the other hand, is the dependent variable with the following indicators as proposed by Kimaite (2016): participation which refers to the activities and degree of adherence of the management and stakeholders to the process of accountability; evaluation which refers to monitoring frameworks which enhances accountability; and fiscal compliance which focuses on how to adhere with financial sector policies, rules and regulations.

\section{RESEACH METHOD}

Research Design. This study utilized a quantitative, nonexperimental research design with the application of correlational technique to determine the significant influence of internal control on the accountability of credit cooperatives in Panabo City. A quantitative design begins by looking at a theory, produces hypotheses from that theory, and then proceeds to test that theory (Greener, 2008) and involves collecting a standard range of quantitative data from a significant sample of respondents through use of survey 
questionnaires (Mersdorf, 2016). To test the theory that internal control affects accountability of credit cooperatives in Panabo City, this study used the survey questionnaire. This study was non-experimental because the researcher did not control, manipulate or alter the predictor variable or subjects, but instead, relied on interpretation, observation or interactions to come up with a conclusion (Kowalczyk, 2017). Thus, this study did not involve treating or changing the data. Moreover, this study used correlational technique which is concerned with establishing relationships that exist among variables and describes them in relation to their direction, either positive or negative (Cook \& Cook, 2008). The relationships of the independent and dependent variables of this study were checked and interpreted to determine emerging trends and patterns.

Data Sources and Variables. The respondents were the employees of credit cooperatives in Panabo City. For this study, there were no required age, sex, ethnicity, employment status and years of work experience of the respondents, as long as they are presently employed in the credit cooperatives in Panabo City. Currently, there are four credit cooperatives in Panabo City with a total of 108 employees. The credit cooperatives found in this locale and the number of employees for each credit cooperative are the following: Credit Cooperative A, 70; Credit Cooperative B, 19; Credit Cooperative C, 9; and, Credit Cooperative D, 10.

This study employed the total population sampling which included all employees from all credit cooperatives in Panabo. Total population sampling, as defined by Etikan (2016), is a purposive sampling which is the deliberate choice of a participant due to the qualities the participant possesses. Simply, the researcher decides what needs to be known and sets out to find people who can and are willing to provide the information by virtue of knowledge or experience.

Statistical Treatment of Data. The data gathered through the questionnaires were tallied and treated using the following statistical tools:

Mean. This is the average of numbers. This was utilized to meet the first and second objective of the study specifically to identify the level of the internal control and accountability of credit cooperatives in Panabo City.

Pearson $r$. This is a measure of linear correlation of the independent and dependent variable. This statistical treatment was used in this study to determine the significance of relationship between internal control and accountability of credit cooperatives in Panabo City.

Regression Analysis. This tool was used to predict the value of a variable based on the value of two or more other variables. It was used to determine which among the specific domain of internal control best influences accountability of credit cooperatives in Panabo City.

\section{RESULTS AND DISCUSSION}

Internal Control of Credit Cooperatives. The level of internal control of credit cooperatives as perceived by the employees is shown in Table 1. The results revealed that the overall mean was 4.61 with a descriptive level of very high, meaning internal control of credit cooperatives is always manifested. The results further revealed that the risk assessment obtained the highest mean of 4.66 while control activities got the lowest mean of 4.57 , all with the same descriptive level of very high.

Table 1.

Level of Internal Control of Credit Cooperatives

\begin{tabular}{lccc}
\hline Indicator & SD & Mean & Descriptive Level \\
\hline Control environment & 0.63 & 4.62 & Very High \\
Control activities & 0.66 & 4.57 & Very High \\
Risk assessment & 0.62 & 4.66 & Very High \\
Information and communication & 0.66 & 4.60 & Very High \\
Monitoring & 0.63 & 4.65 & Very High \\
& 0.65 & 4.61 & Very High \\
\hline
\end{tabular}

Accountability of Credit Cooperatives. Presented in Table 2 is the level of accountability of credit cooperatives in terms of participation, evaluation, and fiscal compliance. The results revealed that the overall mean was 4.60 , with a descriptive level of very high. This means that the accountability of credit cooperatives is always manifested. The result further revealed that fiscal compliance posted the highest mean of 4.62 and participation obtained the lowest mean of 4.58 , all with the same descriptive level of very high.

\begin{tabular}{lccc}
$\begin{array}{l}\text { Table } 2 . \\
\text { Level of Accountability of Credit Cooperatives }\end{array}$ & & \\
\hline Indicator & SD & Mean & Descriptive Level \\
\hline Participation & 0.66 & 4.58 & Very High \\
Evaluation & 0.65 & 4.60 & Very High \\
Fiscal compliance & 0.61 & 4.62 & Very High \\
Overall & $\mathbf{0 . 6 4}$ & $\mathbf{4 . 6 0}$ & Very High \\
\hline
\end{tabular}

Significance on the Relationship between Internal Control and Accountability of Credit Cooperatives. Presented in Table 3 are the results of the test of significance in the relationship between the variables involved in the study. The overall correlation had a computed r-value of 0.804 with a p-value of 0.000 , which is significant at 0.05 level. The first null hypothesis stating that there is no significant relationship between internal control and accountability of credit cooperatives in Panabo City, is thus rejected.

Doing a correlation among the indicators of both variables, it can be gleaned that accountability revealed overall $r$-values ranging from 0.715 to 0.796 with p-values of 0.000 which is lesser than the 0.05 level of significance. This showed that the 
higher the internal control, the higher the accountability of credit cooperatives in Panabo City.

As indicated in the table, control environment, control activities, risk assessment, information and communication, and monitoring were significantly related to overall accountability with computed r-values ranging from 0.697 to $0.793, \mathrm{p}<0.05$.

\begin{tabular}{|c|c|c|c|c|}
\hline & & & & \\
\hline & & & & \\
\hline Internal Control & Participation & Evaluation & $\begin{array}{c}\text { Fiscal } \\
\text { compliance }\end{array}$ & Overall \\
\hline Control environment & $0.573^{\star \star}$ & $0.708^{\star \star}$ & $0.695^{* *}$ & $0.697^{\star \star}$ \\
\hline & $(0.000)$ & $(0.000)$ & $(0.000)$ & $(0.000)$ \\
\hline Control activities & $0.694^{\star *}$ & $0.773^{\star \star}$ & $0.782^{* \star}$ & $0.793^{* *}$ \\
\hline & $(0.000)$ & $(0.000)$ & $(0.000)$ & $(0.000)$ \\
\hline Risk assessment & $0.643^{* \star}$ & $0.739^{\star \star}$ & $0.704^{* *}$ & $0.736^{\star \star}$ \\
\hline & $(0.000)$ & $(0.000)$ & $(0.000)$ & $(0.000)$ \\
\hline $\begin{array}{l}\text { Information and } \\
\text { communication }\end{array}$ & $0.675^{\star \star}$ & $0.721^{\star \star}$ & $0.714^{* \star}$ & $0.745^{\star \star *}$ \\
\hline & $(0.000)$ & $(0.000)$ & $(0.000)$ & $(0.000)$ \\
\hline Monitoring & $0.717^{\star \star \star}$ & $0.736^{\star \star}$ & $0.653^{* *}$ & $0.744^{* \star}$ \\
\hline & $(0.000)$ & $(0.000)$ & $(0.000)$ & $(0.000)$ \\
\hline Overall & $0.715^{\star \star}$ & $0.796^{\star \star}$ & $0.768^{\star \star}$ & $0.804^{* *}$ \\
\hline & $(0.000)$ & $(0.000)$ & $(0.000)$ & $(0.000)$ \\
\hline
\end{tabular}

Significance on the Influence of Internal Control on Accountability of Credit Cooperatives. Presented in Table 4 is the significance on the influence of internal control on accountability of credit cooperatives in Panabo City. It was revealed that the F-value was 41.566 with a p-value of 0.000 , which indicate that internal control significantly influences the accountability of credit cooperatives in Panabo City.

The result also displayed an $\mathrm{R}$ value 0.819 , with an $\mathrm{R} 2$ value of 0.671 , which meant that 67.10 percent of the variance of accountability can be best explained by internal control. The other 32.90 percent can be attributed to other variables not covered in this study.

When taken individually, the result showed that the control environment, risk assessment, and information and communication showed no significant influence on accountability of credit cooperatives. The support of other indicators is needed for the combined influence. Only control activities and monitoring measures of internal control posted significant influence on accountability. Between the two, control activities emerged as the best predictor of accountability given a higher Beta coefficient of 0.452 .

This rejects the second null hypothesis, stating that there is no domain of internal control that best influences the accountability of credit cooperatives in Panabo City.
Table 4

Significance of Intemal Control and Accountability of Credit Cooperatives

\begin{tabular}{|c|c|c|c|c|c|}
\hline \multirow{2}{*}{\multicolumn{2}{|c|}{$\begin{array}{l}\text { Internal control } \\
\text { (Indicators) }\end{array}$}} & \multicolumn{4}{|c|}{ Accountability } \\
\hline & & $B$ & $\mathrm{~B}$ & $t$ & Sig \\
\hline Control environment & & -0.037 & -0.037 & -0.305 & 0.761 \\
\hline Control activities & & 0.452 & 0.428 & 2.925 & 0.004 \\
\hline Risk assessment & & 0.045 & 0.043 & 0.322 & 0.748 \\
\hline $\begin{array}{l}\text { Information and } \\
\text { communication }\end{array}$ & & 0.128 & 0.117 & 0.923 & 0.358 \\
\hline \multirow[t]{5}{*}{ Monitoring } & & 0.282 & 0.281 & 2.942 & 0.004 \\
\hline & $\mathrm{R}$ & 0.819 & & & \\
\hline & $\mathrm{R}^{\wedge} 2$ & 0.671 & & & \\
\hline & $\mathrm{F}$ & 41.566 & & & \\
\hline & $\mathrm{P}$ & 0.000 & & & \\
\hline
\end{tabular}

Discussion. The study revealed that the overall level of internal control is very high, which means that internal control as perceived by the employees of credit cooperatives is always manifested. The very high result is due to very high rating given by the respondents on control environment, control activities, risk assessment, information and communication, and monitoring. This confirms the pronouncement of Bubilek (2017) along with other authors, Gaku (2014); Vollbehr (2014); and Yurniwatia and Rizaldi (2005) that the presence of control environment, control activities, risk assessment, information and communication, and monitoring will help an organization establish a well-functioning internal control.

For the level of accountability among credit cooperatives, the results showed that the overall level of accountability is very high. The very high level of accountability of credit cooperatives in Panabo City is due to the very high rating given by the respondents on these cooperative's fiscal compliance and evaluation, as well as participation. The management of credit cooperatives provides adequate information when making accountable reports, conducts resource monitoring and has the right priorities set during the budgeting process. These practices are expected to increase the accountability of credit cooperatives, as viewed by various authors (Blagescu et al., 2005; Poto \& Fornabio, 2017; Marenakos, 2011; Kimaite, 2016) who pronounced that accountability is increased by providing adequate information and having right priorities in implementing internal control, among others.

The results of the study confirmed that internal control has a significant relationship to accountability of credit cooperatives since the result showed a p-value less the level of significance.

The results agreed with the proposition of Steinhoff (2005) that the key to accountability is an effective internal control, since, internal control relies on the management, the failure of the management to establish proper control environment, implement control activities, assess associated risks, handle information and communicate such properly and monitor if controls are still in place, means it is to be held 
accountable for the consequences of their actions. Thus, for the management to be accountable for their actions, an internal control must be established that gives rewards for doing right things and consequences for doing the wrong things.

Furthermore, this supports Morehead (2007) who posited that the absence of an effective internal control will make it possible for anyone to conduct fraud and corruption, thus, manifesting a low level of accountability. It will also make the stakeholders think that the management is incapable of what they have entrusted to them. Moreover, credit cooperatives, to promote accountability, need to engage its stakeholders to participate in making decisions, to evaluate the performance and the results of such, and lastly, to comply with standards and laws of financial and regulatory bodies. In addition, the internal control serves as the first line of defense in safeguarding assets and preventing or detecting errors, fraud, waste, abuse and mismanagement. Therefore, internal control is at the heart of accountability (Abdirisaq \& Yassin, 2014).

Lastly, Kewo (2017) along with other authors (Gaku, 2014; Fernando \& Yukawa, 2013; Karagiorgos et al., 2011; Palfi \& Bota-Avram, 2009; Masli et al., 2009; Yurniwatia \& Rizaldi, 2005) noted that if the implementation of internal control such as creating a positive atmosphere that will make everyone aware of the relevance of internal control, maintaining clear internal policies and regulations, keeping records of trainings and achievements of employees, and having a fair and adequate level of segregation of duties can promote accountability.

Further, it was added that well-functioning internal control can be manifested by encouraging fraud reporting from employees, and taking suitable actions to counteract for the future, considering the associated risks and to know how to handle those risks, having internal control of information and communication which addresses the threat of unauthorized access to an information by an insider or outsider, and having periodic assessment or regular reminder to all personnel on how internal control should operate to promote greater accountability. Lastly, the results agree with the proposition of Mattie et al. (2005) that internal control is the key to accountability. To achieve accountability, there must be a determination of how the institution defines individual accountability and responsibility for key activities at every level; identification of the institution's most significant risks; evaluation of the institution's control activities such as its policies and procedures; identification of information's need; and development of a communication strategy to get the right information into the hands of the employees who need it to carry out their responsibilities; and establishment of follow-up procedures, such as staff supervision, to make sure that controls are working as intended.

The result of the study revealed that internal control significantly influences accountability of credit cooperatives having a p-value of less than the level of significance. The R- squared of sixty-seven point ten percent means that the variance of accountability can be explained by internal control at around sixty-seven point ten, the other thirty-two point ninety percent can be attributed to other variables not covered in the study. The result further showed that on the singular level, the control environment, risk assessment and information and communication showed no significant influence on accountability. It requires control activities and monitoring to assimilate influence. On the other hand, control activities and monitoring of credit cooperatives solely can significantly influence accountability of credit cooperatives.

This is parallel to the study of Mwangi (2011) that among the five elements of internal control, control activities have contributed more to the success of the internal control. Furthermore, Masli et al. (2009) and Vollbehr (2014) emphasized that any control deficiencies on internal control can be timely detected and can be dealt with properly if there is a well-designed and functional monitoring program.

Also, the result is in corroborates the study of Widyaningsih (2015) on the influence of internal control system on the financial accountability of elementary schools in Bandung, Indonesia that control environment, supervision and control activities such as policies, procedures and practices designed to improve risk management strategy which significantly affects financial accountability.

\section{CONCLUSIONS AND RECOMMENDATIONS}

Based on the results of the study, the following conclusions were drawn:

The internal control of credit cooperatives is very high, and the result reveals that the indicators control environment, control activities, risk assessment, information and communication, and monitoring are also very high. Next, the study reveals a very high accountability of credit cooperatives as perceived by the employees. Further, it also reveals a very high satisfaction on participation, evaluation, and fiscal compliance. Furthermore, the internal controls of credit cooperatives are significantly related to the accountability of credit cooperatives. Lastly, internal controls of credit cooperatives significantly influence accountability, especially control activities and monitoring.

Therefore, the results of the study agree and confirm the proposition of Ntongo (2012) that any practices which is connected to internal control can influence or impact accountability of credit cooperatives.

Based on the conclusions of the study, the following are highly recommended:

This study, with the very high level of internal control of credit cooperatives, suggests that credit cooperatives use internal control tools on human resources to evaluate the level of productivity, effectiveness and efficiency of its human resources, use the complaints from other stakeholders as a tool of internal control, have plan B for any surprised changes that might affect the work in the credit cooperative, pass the 
information and duties by the management to its employees clearly and smoothly and study the received complaint to find out its cause to take the appropriate actions.

Moreover, the very high level of accountability of credit cooperatives should be maintained by engaging the stakeholders to participate in its decision making such as conducting general assemblies and meetings. It is further suggested that the management should provide tracking variances and backflush and should adhere to accountability procedures governing the credit cooperative sector.

Since the result showed that there is a significant relationship between internal control and accountability of credit cooperatives specifically on control activities and monitoring, it is recommended that the control environment, risk assessment and information and communication be strengthened to satisfy their employees further.

The result revealed that only sixty-seven point ten percent of the behavior of accountability can be explained by internal control; it is therefore recommended that further study be conducted to find out what factors significantly influence accountability.

\section{ABOUT THE AUTHOR}

The author is a Certified Public Accountant (CPA), a Certified Tax Technician (CTT) and has completed her master's degree in Accountancy at the age of 25 years from The University of Mindanao, Philippines. She is the eldest among the three children of Mrs. Rowena and Mr. Dennis M. Beloy. She is the Chief Accountant of Ultra Bowl, Inc., a corporation engaged in restaurant and other services and a part-time university professor of UM Panabo College from 2016 up to present.

\section{REFERENCES}

[1] Abdirisaq, I. M., \& Yassin S.A. (2014). Assessing the financial accountability of the Somali Federal Government organisations. Public Pol. Adm. Res. 4(3):61-66

[2] Abiola, J. (2013). The impact of information and communication technology on internal controls prevention and detection of fraud (Unpublished doctoral dissertation). De Montfort University, England.

[3] Ayyash, M. Y. (2017). The impact of internal control requirements on profitability of Palestinian shareholding companies (Unpublished master's thesis). The Islamic UniversityGaza, Palestine.

[4] Azadinamin, A. (2013). The bankruptcy of Lehman brothers: causes of failure \& recommendations going forward. Swiss Management Center (SMC) University.

[5] Blagescu, M., de las Casas, L., \& Lloyd, R. (2005). Pathways to accountability: the GAP framework. London: One World Trust.

[6] Bubilek, O. (2017). Importance of internal audit and internal control in an organization - case study (Unpublished bachelor's thesis). Arcada University of Applied Sciences, Finland.

[7] Chen, F. (2015). An investigation and evaluation of risk assessment methods in information systems (Unpublished master's thesis). Chalmers University of Technology, Sweden.

[8] Committee of Sponsoring Organizations of the Treadway Commission (2013). Integrated control - integrated framework [ExecutiveSummary].Retrievedfromhttps://na.theiia.org/standards guidance/topics/documents/executive_summary.pdf

[9] Cook, B. G., \& Cook, L. (2008). Nonexperimental quantitative research and its role in guiding instruction. Intervention in School
andClinic Volume, 44(2), 98-104. doi: $10.1177 / 1053451208321565$

[10] Dossing, H., Letshego, M., \& Weideman, M. (2011). Mapping transparency, accountability and integrity in primary education in SouthAfrica[Pdf].Retrievedfromhttp://www.un.org/en/ecosoc/newf unct/pdf/luxembourg_tisda_south_africa_report_web.pdf

[11] Eskelinen, J. (2016). Conducting risk assessment cloud provider perspective (Unpublished master's thesis). Helsinki Metropolia University of Applied Sciences, Finland.

[12] Etikan, I. (2016). Comparison of convenience sampling and purposive sampling. American Journal of Theoretical and Applied Statistics, 5(1), 1-4. doi:10.11648/j.ajtas.20160501.11

[13] Fernando, S. A., \& Yukawa, T. (2013). Internal control of secure information and communication practices through detection of user behavioral patterns. World Congress on Engineering 2013 Vol II. doi:978-988-19252-8-2

[14] Gaku, L. G. (2014). The relationship between internal control systems and revenue collection efficiency in water services providers in the Athi water services board (Unpublished master's thesis). University of Nairobi, Kenya.

[15] Greener, S. (2008). Business research methods. Ventus Publishing: BookBoon.

[16] Huque, A. S. (2011). Accountability and governance: Strengthening extra-bureaucratic mechanisms in Bangladesh. International Journal of Productivity and Performance Management, 60(1), 59-74. doi:10.1108/17410401111094312

[17] Karagiorgos, T., Drogalas, G., \& Giovanis, N. (2011). Evaluation of the effectiveness of internal audit in Greek hotel business. International Journal of Economic Sciences and Applied Research, 4 (1), 19-34. Available atSSRN: https://ssrn.com/abstract=1806943

[18] Keay, A., \& Loughrey, J. (2015). The framework for board accountability in corporate governance. Legal Studies, 35(2), 252279. doi:10.1111/lest.12058

[19] Kewo, C. L. (2017). The influence of internal control implementation and managerial performance on financial accountability local government in Indonesia. International Journal of Economics and Financial Issues, 7(1), 293-297.

[20] Kimaite, N. (2016). Corporate governance and organizational performance of commercials banks in Uganda: a case of Stanbic Bank Uganda Limited (Unpublished master's thesis). Uganda Technology and Management University, Africa.

[21] Kowalczyk, D. (2017). Non-Experimental and Experimental Research: Differences, Advantages \& Disadvantages. Retrieved fromhttp://study.com/academy/lesson/non-experimental-andexperimental-research-differences-advantages-disadvantages.html

[22] Kumuthinidevi, S. (2016). A study on effectiveness of the internal control system in the private banks of Trincomalee. International Journal of Scientific and Research Publications (IJSRP), 6 (4), June 2016.

[23] Marenakos, L. (2011). Accountability matters [Pdf]. Retrieved from

https://www.blackbaud.com/files/resources/downloads/WhitePape r_Accountability_Full.pdf

[24] Masli, A., Peters, G.F., Richardson, V.J., \& Sanchez, J.M. (2009). Examining the potential benefits of internal control monitoring technology. The Accounting Review, 85 (3), 1001-1034

[25] Mattie, J. A., Hanley, P. F., Cassidy, D. L., \& Broad, M. C. (2005). Internal controls: The key to accountability. Pricewaterhouse: Cooper.

[26] Mersdorf, S. (2016). Qualitative vs. quantitative research methods. Retrieved from https://blog.cvent.com/events/feedbacksurveys/qualitative-vs-quantitative-research-methods/

[27] Mohamad, M., Othman, I., \& Mohamed, A. (2013). Accountability issues and challenges: the scenario for Malaysian cooperative movement. World Academy of Science, Engineering and Technology, International Science Index 78, International Journal of Social, Behavioral, Educational, Economic, Business and Industrial Engineering, 7(6), 1503 - 1508

[28] Morehead, W. A. (2007). Internal control and governance in nongovernmental organizations designed to provide accountability 
and deter, prevent and detect fraud and corruption (Order No. 3300861). Available from ProQuest Central. (304808938). Retrievedfromhttps://search.proquest.com/docview/304808938?ac countid $=3125$

[29] Mwangi, L. M. (2011). An investigation of the relationship between the internal controls and financial performance of alexander Forbes financial services of (EA) limited (Unpublished master's thesis). University of Nairobi, Kenya.

[30] Noorvee, L. (2006). Evaluation of the effectiveness of internal control over financial reporting (Unpublished master's thesis). University of Tartu, Estonia.

[31] Ntongo, V. (2012). Internal controls, financial accountability and service delivery in private health providers of Kampala district (Unpublished master's thesis). Makerere University, Uganda.

[32] Palfi, C., \& Bota-Avram, C. (2009). Information and communication in banks - key elements of the internal control system - an empirical analysis between Romanian, American and Canadian models of control. Annals of Faculty of Economics, University of Oradea, Faculty of Economics, 3(1), 1091-1096, May 2009.
[33] Poto, M. P., \& Fornabaio, L. (2017). Participation as the essence of good governance: some general reflections and a case study on the Arctic Council. Arctic Review on Law and Politics,8(0). doi:10.23865/arctic.v8.714

[34] Selaratana, S. (2009). Accountability in the Thai public sector (Published doctoral dissertation). University of Glasgow, Thailand. Retrieved from http://theses.gla.ac.uk/1280/

[35] Steinhoff, J. C. (2005). Effective internal control is key to accountability. United States Government Accountability Office. Retrieved from https://www.gao.gov/products/GAO-05-321T

[36] Vollbehr, L. (2014). Implementing the monitoring activities component of the coso framework (Unpublished master's thesis). Aalto University School of Business, Finland.

[37] , Yurniwati \& Rizaldi, Afdhal. (2015). Control Environment Analysis at Government Internal Control System: Indonesia Case. Procedia - Social and Behavioral Sciences. 211. 844-850. 10.1016/j.sbspro.2015.11.111.

[38] Zvavahera, P., \& Ndoda, G. R. (2014). Corporate governance and ethical behaviour: The case of the Zimbabwe broadcasting corporation. Journal of Academic and Business Ethics, 9. 